\title{
The Accuracy of Various Value Drivers of Price Multiple Method in Determining Equity Price
}

\author{
Pisal YOOYANYONG ${ }^{1}$, Issara SUWANRAGSA ${ }^{2}$, Nopphon TANGJITPROM ${ }^{3}$
}

Received: September 06, 2019 Revised: November 01, 2019 Accepted: November 15, 2019

\begin{abstract}
Stock price multiple is one of the most well-known equity valuation technique used to forecast equity price. It measures by multiplying "the ratio of stock price to a value driver" by a value driver. The value driver can be earning per share (EPS), sales or other financial measurements. The objective of price multiple technique is to evaluate the value of assets and compare how similar assets are priced in the market. Although stock price multiple technique is common in financial filed, studies on the application of the technique in Thailand is still limited. The present study is conducted to serve three major objectives. The first objective is to apply the technique to measure value of firms in banking sector in the Stock Exchange of Thailand. The second objective is to develop composite price multiple index to forecast equity prices. The third objective is to compare valuation accuracy of different value drivers of price multiple (i.e. EPS, Earnings Growth, Earnings Before Interest Taxes Depreciation and Amortization, Sales, Book Value and Composite Index) in forecasting equity prices. Results indicated that EPS is the most accurate value drivers of price multiple used to forecast equity price of firms in baking sector.
\end{abstract}

Keywords : Finance, Price Multiple, Valuation Accuracy, Value Drivers, Stock Exchange of Thailand

JEL Classification Code : G12

\section{Introduction}

The question of how to determine stock price is a major concern of academicians, financial analysts, firms and investors. Due to a fluctuation in equity prices, it is important for academicians, financial analyst, firms, and investors to understand how to evaluate the value of equity

1 First Author and Corresponding Author, Senior Business Development Manager, Business Development \& Engineering Department, DSV Solutions Limited, Thailand. [Postal Address: 89/40, Life Bangkok Boulevard Village, Kanchanapisek Road, Praves, Bangkok, 10250, Thailand] Email: jaded_nd@hotmail.com

2 Lecturer, Martin de Tours School of Management and Economics Department, Business Administration, Assumption University, Thailand. Email: Issaraswn@au.edu

3 Program Director, Martin de Tours School of Management and Economics Department, Business Administration, Assumption University, Thailand. Email: tnopphon@gmail.com Email: Samarhabib@gmail.com

(c) Copyright: Korean Distribution Science Association (KODISA) This is an Open Access article distributed under the terms of the Creative Commons Attribution Non-Commercial License (http://Creativecommons.org/licenses/by-nc/4.0/) which permits unrestricted noncommercial use, distribution, and reproduction in any medium, provided the original work is properly cited. to formulate investment strategy in managing assets and portfolio. Incorrectly evaluated equity prices may results in misinterpretation of the value of the firm, fluctuation in equity price, fluctuation in the stock market, and deteriorate of firms' performance and stock market performance. Incorrectly selection of valuation method may hinder ability of financial counselors and analysts to recommend the value of equity, resulting in misleading the performance of firms and stock markets.

To improve assessment of equity valuation, Liu, Nissim and Thomas (2002) and Yoo (2006) introduced "the stock price multiple to an accounting performance" as another technique for equity valuation. Stock price multiple valuation technique has received attention from academicians and investment practitioners in measuring firms' intrinsic value and determining the expected equity prices for decades. It can be calculated by multiplying "the multiple" by a value driver. The multiple defines as the ratio of stock price of the company to a value driver (Liu et al., 2002). Value drivers can be earnings per share (EPS), sales, book value of the company or other accounting performance measurements (Liu et al., 2002). Liu et al. (2002) studied 
price multiple valuation of book value of equity, sales, earnings, EBITDA, operational cash flow, earnings growth forecast, free cash flow, and maintenance cash flow and found that forward earnings multiple explains stock prices well.

Yoo (2006) used composite price multiples and found that the valuation outcomes of the composite price multiple provide greater valuation result than simple price multiple approach. The price multiples include book value of equity, sales, EBITDA and earnings forecast. The strengths of this valuation technique lie in its simplicity, comprehensiveness, and more accuracy than simple financial ratio. It does not require data on multi-year forecasts of probability, cost of equity, and growth (Yoo, 2006). Liu et al. (2002) indicated that price multiple technique is a more comprehensive valuation method as it reflects all available information and it is applied to find the value while the pricing errors are in the process of correction. Baker and Ruback (1999) indicated that price multiple valuation technique implicitly assumes appropriate future cash flows and discount rate. Price multiple of financial performance is used for measuring firms' value. Price multiple technique uses current industry growth rate and market's required rate of return. The technique avoids the difficulty finding an appropriate discount rate used in discounted cash flow technique and determining future cash flows (Baker \& Ruback, 1999).

Although price multiple valuation technique has gained popularity in measuring firms' intrinsic value and forecasting equity prices in several oversea equity markets, there is limited published research papers that measure and forecast values of Thai listed firms using price multiple valuation technique. In addition to limited literature on price multiple valuation in Thailand, previous studies had examined only some value drivers (such as EBITDA, sales, or book value) of stock price multiple and had not provided the conclusion on which value driver was the most accuracy in determining equity prices. To fill this gap, the present study contributes to existing literatures by examining the values of banking companies listed in the Stock Exchange of Thailand using various value drivers of price multiple and comparing the accuracy of various value drivers of price multiple (i.e. EPS, price earnings growth, EBITDA, sales and book value of equity) to find the most accurate value driver for companies in the Thai stock exchange market. Furthermore, since each value driver used in simple price multiple valuations may not be able to reflect the incremental information that improves the valuation accuracy of the other value drivers, the present research develops a composite index that combines several value drivers into one measurement and examines whether the composite approach can enhance the accuracy of valuation technique rather than the single value driver of price multiple.

The banking sector of Stock Exchange of Thailand includes the following banks; Bank of Ayudhya PLC, Bangkok Bank PLC, CIMB Thai PLC, Kasikorn Bank PLC,
Kiatnakin Bank PLC, Krungthai Bank PLC, LH Financial Group PLC, Siam Commercial Bank PLC, Thanachart Capital PLC, TISCO Financial Group PLC and Thai Military Bank PLC. The banking sector is the second largest sector in the Stock Exchange of Thailand with the market capitalization of THB 2,417,288.13 million representing $15.13 \%$ of the total market capitalization in 2017. The total market capitalization is THB 17,587,433,31 million (Stock Exchange of Thailand, 2019). The average daily transaction amount of banking sector in 2017 was THB 5,657.72 million representing $11.85 \%$ of the total daily transaction. Banking sector plays an important role in Thai economy as it provides funds to companies in other sectors and it is an indicator sector of the economy.

The present study is conducted to serve three major objectives. The first objective is to measure value of banking companies listed in the Stock Exchange of Thailand through different values drivers of price multiple valuation technique. The second objective is to develop composite index of price multiple valuation technique to measure firm equity prices. The third objective is to compare among several value drivers of price multiple valuation technique and composite price multiple in order to examine which value drivers of price multiple is the most accuracy value driver.

This study provides implications for practitioners, investors and academicians. Thai and international investors could use price multiple valuation technique with various value drivers to determine the stock value of the targeted firms and compare with companies in the same sectors or companies that are similar in term of risk, growth of cash flow and cash. In addition, the present study analyzes and shows the value of the banking companies listed on the Stock Exchange of Thailand. The valuation results can reduce resources and time of practitioners and investors in acquiring information on firm value for investment decisions. The technique can be applied to the companies in other sectors and markets in which it broadens the application of the technique. The findings should also assist academicians, policy makers, and practitioners to evaluate stock prices more accurately. Academically, since price multiple has received less attention than other valuation methods and the research on this subject in Thailand is limited, the findings from the present study should provide additional information for class discussion on price multiple valuation method in an attempt to increase the interest and its applicability through better valuation accuracy results.

\section{Literature Review}

Previous literatures have recommended several techniques to measure value of the firms and predict equity prices. Nel (2009) studied the equity valuation methods that 
are preferred by academicians. Nel (2009) compared five techniques (i.e. price multiple method, discounted cash flow method (DCF), economic value-added model (EVA), net asset base valuation (NAV), and rule of thumb valuation (ROT) used to measure companies' performance and equity prices. Among five techniques, price multiple is one of the most popular methods used by academicians and investment practitioners (Nel, 2009). Kim and Ritter (1999) indicated that when future cash flow projections of companies are imprecise, multiples valuation technique should be used. An empirical result of (Sayed, 2016) indicated, in emerging markets, that DCF models produce different target price forecasts.

Due to poor corporate governance and availability of comprehensive information associated with emerging markets, equity valuation in emerging markets with future information could be affected by reliability of information (Damodaran, 2009). Bekaert and Harvey (2013) found that emerging markets continue to underperform on legal, regulatory and political indicators as compared to developed markets. Sayed (2016) studies methods used to quantity firms' value and equity prices. An in-depth analysis of 392 equity reports was examined to find the accuracy method in measuring firms' performance and forecast equity prices. Results indicated that price/earnings multiple method is a significant better method in measuring firms' value and price in the short-term than DCF methods.

Yoo (2006) indicated that price multiple valuation technique is the most widely used techniques in determining the equity prices in oversea stock markets. It has received attention from academicians and practitioners because of its simplicity and more accuracy than simple financial ratio. Previous studies indicated that analysts prefer using price multiples to other valuation techniques since price multiples are more comprehensive and requires less time spent (Liu et al., 2002; Bradshaw, 2004; Demirakos, Efthimios, Strong, \& Walker, 2004; Asquith, Pathak, \& Ritter, 2005). Damodaran (2009) indicated that relative valuation model probably reflects market perception whereas the DCF model indicates the capability to generate cash flow of a company in the future. Price multiple valuation could be used as a primary valuation method when the availability of information is limited (Nel, 2009). In addition, price multiple technique does not require data on multi-year forecasts of probability, cost of equity, and growth (Yoo, 2006).

Stock price multiple can be calculated by multiplying "the multiple" by value drivers. The multiple defines as the ratio of stock price of the company by value drivers (Liu et al., 2002). The simple price multiple can be calculated as follows:

$$
E V_{i t}=\left(\frac{P}{X}\right) \operatorname{Com}_{i t} \times X_{i t}
$$

Where $E V_{i t}$ is the estimated equity value of firm $\mathrm{i}$ in year $\mathrm{t},\left(\frac{P}{X}\right) \operatorname{Com}_{i t}$ is the harmonic mean of the stock price $(\mathrm{P})$ multiple to a value driver $(\mathrm{X})$ of comparable firm $\mathrm{i}$ in year $\mathrm{t}$ and $X_{i t}$ is the value driver of firm i in year t.

Previous literatures (i.e. Kim \& Ritter, 1999; Liu et al., 2002; Yoo, 2006) have recommended various value drivers as a measurement of equity value and predicting equity price, i.e. sales, EPS, book value, or other performance measurements. An empirical study of Kim and Ritter (1999) showed that forward earnings provide higher accuracy over other value drivers of price multiple. Liu et al. (2002) indicated that when forward earning is used as a value driver, it explains stock prices better than cash flow, book value of equity and sales. Empirical results of Beatty, Riffe, and Thompson (1999) indicated that EPS and book value of equity provide the highest accuracy using the weighted derived from the price-deflated regression. Yoo (2006) found that using forecast earnings as a value driver provides the highest accuracy followed by historical earnings, earnings before interest, taxes, depreciation and amortization (EBIDA), book value of equity and sales. Bhojraj and Lee (2002) suggested that sales and book value of equity is the accurate value drivers of price multiple technique. Kaplan and Ruback (1995) suggested using EBITDA as a value driver of price multiple. EBITDA price multiple provides accuracy as much as discount cash flow valuation technique (Kaplan \& Ruback, 1995). Tasker (1998) indicated that the best value driver of price multiple is different in various industries since each industry differs in the source of revenue, source of cost, asset, liabilities and equities.

Since previous studies have suggested several value drivers as a measurement of firm's value in predicting stock price and there still be no conclusion on which value driver is the best, the present study aims to determine the best value driver among the selected five value drivers, i.e. earnings, sales, EBITDA, book value of equity, and price earnings growth. In addition, the present study develops composite index of price multiple and compares its accuracy performance with the simple price multiple valuation measurements.

\section{Research Methods and Materials}

\subsection{Collection of Data}

Target population of the present study included 11 listed companies in the banking sector in the Stock Exchange of Thailand. The banking sector is selected because it has received more attention from academicians, investors, and financial counselors. The selected companies include; Bank of Ayudhya, Bangkok Bank, CIMB Thai Bank, Kasikorn Bank, Kiatnakin Bank, Krung Thai Bank, LH Financial GP, Siam Commercial Bank, Thanachart Capital, Tisco Financial Group and Thai Military Bank. As price multiple technique requires price multiple ratio of comparable firms to calculate the estimated equity value of target firms (Liu, et al., 2002), comparable firms should have similar cash flows, growth potential, and risk similar to the firm being valued 
(Damodaran, 2001). Only firms that have positive values for any value drivers are included in the sample. Value drivers in this research include EPS, price earnings growth ratio, EBITDA (earnings before interest, taxes, depreciation and amortization), sales, book value of equity and composite index of price multiple. Data is collected from Thomson Reuters' database. The period of the study is from January 2001 to December 2018.

\subsection{Measurements of Variables}

The estimated equity values of firms are measured by equation (1). The value driver in the present study include EPS, price earnings growth ratio, EBITDA, sales, book value of equity and composite index of price multiple. These variables are selected based on the findings of previous studies that they capture most of the information which relates to equity prices (Yoo, 2006).

In addition, the present study includes price earnings growth ratio as a new factor in price multiple valuation research as it measures the earnings growth of equity in which investors consider when buying stocks. Price earnings growth $(\mathrm{P} / \mathrm{EG})$ defines as the ratio of equity price divided by analyst's earning per share forecast for next year (Liu et al., 2002). P/EG also allows the forecasted growth to vary for different companies. In the present study, the earnings growth is calculated by taking the earnings per share of current year minus earnings per share of previous year and dividing by earnings per share of previous year. P/EG price multiple is calculated as follows:

$$
E V_{i t}=\left(\frac{P E}{G}\right) \operatorname{Com}_{i t} x \text { Earnings }_{i t} x \text { Earnings Growth }_{i t}
$$

where $E V_{i t}$ is the estimated equity value of target firm i in year t. $\left(\frac{P E}{G}\right) \operatorname{Com}_{i t}$ is the harmonic mean of the price earnings (PE) multiple to growth (G) per share of comparable firms $\mathrm{i}$ in year t. Earnings Et $_{i t}$ is the earnings per share of target firm i in year t. Earnings Growth $_{i t}$ is the earnings growth per share of target firm $i$ in year $t$.

\subsection{Procedure}

The procedure to calculate price multiple is described as followed. First, according to Liu et al. (2002) and Yoo (2006), the equity price at the last trading day of April each year from 2001-2018 is used as it is the price after firms announce their fourth quarter earnings of the previous year. Second, measurements of each value driver, i.e. EPS, price earnings growth, EBITDA, sales, and book value of equity in December each year from 2000-2017 of each firm is taken. Third, the expected equity value of target firm in each year is calculated by equation (1).

\subsection{Composite Index of Price Multiple Valuations}

In order to combine valuation outcomes of other simple price multiple, the following procedure is conducted. First, equity price of target firm as of last trading day of April each year is taken. Second, target firm's expected equity value from each price simple multiple valuations are added and divided by number of value drivers to get the average expected equity value as below equation.

$$
E V_{i t}=\frac{E V_{E A R N I N G i t}+E V_{E B I T D A i t}+E V_{B V i t}}{n}
$$

Where $E V_{\text {EARNINGit }}$ is the expected equity value of firm $\mathrm{i}$ in year $\mathrm{t}$ calculated by earnings, EV EBITDAit is the expected equity value of firm $i$ in year $t$ calculated by earnings before interest, taxes, depreciation and amortization and $E V_{B V i t}$ is the expected equity value of firm $\mathrm{i}$ in year $\mathrm{t}$ calculated by book value of equity.

\subsection{Measurements of Valuation Accuracy}

In the present study, three statistical methods are used to measure the accuracy of each value driver of price multiple. Each one measures the magnitude of the valuation errors in different ways. The three measurements of valuation accuracy include (1) the mean of absolute valuation errors (MAVE), (2) the interquartile range of valuation errors (IQRVE) and (3) the percentage of sample whose absolute percentage valuation error is over 15 per cent (15\% AVE).

\subsubsection{Mean Absolute Valuation Error (MAVE)}

MAVE is the average of all absolute valuation errors. It shows the difference between the absolute forecasted value and the absolute actual value and indicates average deviation of an error from the forecast.

$$
M A V E=\frac{1}{n} \sum_{i=1}^{n}\left|x_{i}-x\right|
$$

Where $\mathrm{n}$ represents number of errors, $\Sigma$ is the summation symbol, $x_{i}$ is actual value, $x$ is forecasted value and $\left|x_{i}-x\right|$ is the absolute errors. The calculation starts with finding all of absolute errors $\left(\mathrm{x}_{\mathrm{i}}-\mathrm{x}\right)$, adding them all up and dividing summation outcome by the number of errors.

3.5.2. Interquartile Range of Valuation Errors (IQRVE)

The interquartile range measures where the "middle fifty" is in a data set from 2001-2018. To compute the interquartile range for this example set of data $1,2,3,4,5,6,7,8,9,10$, 11, the median (6) is identified and the parentheses are put above and below the median $(1,2,3,4,5), 6,(7,8,9,10$, 11). 3 is a median of lower half of the numbers and represents Q1 and 9 is a median of upper half of the numbers and represents Q3. To calculate the interquartile range, the third quartile is subtracted by the first quartile; $\mathrm{IQR}=\mathrm{Q} 3-\mathrm{Q} 1$. An interquartile range of above example is 
$9-3=6$. Interquartile is the most significant basic robust measure of scale. The IQR is a measure of variability.

3.5.3 The Percentage of Sample Whose Absolute Percentage Valuation Error over 15\% (15\% AVE)

Percentage Valuation Error is calculated by the following formula:

$$
P V E_{i t}=\frac{P_{i t}+E V_{i t}}{P_{i t}}
$$

where $P V E_{i t}$ is percentage valuation error of firm $\mathrm{i}$ in year t. $P_{i t}$ is equity price of firm i in year t. $E V_{i t}$ is expected value of firm $i$ in year $t$.

\section{Results and Discussion}

Table 1: Descriptive Information of Value Drivers

\begin{tabular}{|l|c|c|c|c|c|}
\hline $\begin{array}{c}\text { Unit Per } \\
\text { Share }\end{array}$ & EPS & EG & EBITDA & Sales & BV \\
\hline Mean & 5.06 & 0.17 & 8.94 & 24.23 & 33.02 \\
\hline Median & 3.79 & 0.084 & 7.73 & 15.27 & 19.39 \\
\hline Min & 0.03 & -0.97 & 0.019 & 0.28 & 0.12 \\
\hline Max & 19.10 & 4.63 & 29.22 & 119.55 & 210.45 \\
\hline $\begin{array}{l}\text { Standard } \\
\text { Deviation }\end{array}$ & 5.04 & 0.69 & 8.14 & 25.35 & 40.18 \\
\hline $\begin{array}{l}\text { Number of } \\
\text { Observations }\end{array}$ & 161 & 145 & 157 & 189 & 182 \\
\hline
\end{tabular}

Note: EPS is earnings per share, EG is earnings growth per share, EBITDA is earnings before interest, taxes, depreciation and amortization per share, SALES is sales per share and BV is book value of equity per share.

Table 1 shows descriptive statistics of each value driver of price multiple. First, the mean of earnings per share is 5.06 with the maximum value 19.10 of Kasikorn Bank Public Company Limited in in 2014 and the minimum value 0.03 of CIMB Thai Public Company Limited in 2011. The median of earnings per share is 3.79 and the standard deviation is 5.04. The total number of observations is 161 .

Second, for earning growth (EG), the mean of EG per share is 0.17 with the maximum value 4.63 of Thai Military Bank Public Company Limited in 2006 and the minimum value -0.97 of Thai Military Bank Public Company Limited in 2005. The median is 0.084 and the standard deviation is relatively high 0.69 . The total number of observations is 145 .

Third, the mean of EBITDA per share is 8.94 with the maximum value of 29.22 of Bangkok Bank Public Company Limited in 2012 and the minimum value 0.019 of CIMB Thai Public Company Limited in 2016. The median is 7.73 and the standard deviation is relatively high 8.14 . The total number of observations is 157 .

Fourth, the mean of sales per share is 24.23 with the maximum value of 119.55 of Kasikorn Bank Public Company Limited in 2017 and the minimum value 0.28 of LH Financial Group Public Company Limited in 2011. The median of earnings per share is 15.27 and the standard deviation is 25.35 . The total number of observations is 189 .

Fifth, the mean of book value of equity per share is 33.02 with the maximum value of 210.45 of Bangkok Bank Public Company Limited in 2017 and the minimum value 0.12 of CIMB Thai Public Company Limited in 2007. The median is 19.39 and the standard deviation is relatively high 40.18 . The total number of observations is 182 .

Table 2: Descriptive Information of Various Value Drivers of Price Multiples (Prices to Value Drivers)

\begin{tabular}{|l|c|c|c|c|c|}
\hline $\begin{array}{c}\text { Unit Per } \\
\text { Share }\end{array}$ & P/EPS & P/EG & P/EBTDA & P/Sales & P/BV \\
\hline Mean & 13.54 & -78.29 & 7.80 & 2.16 & 1.73 \\
\hline Median & 10.97 & 20.27 & 6.57 & 2.00 & 1.42 \\
\hline Min & 1.34 & -13109.54 & 0.83 & 0.36 & 0.43 \\
\hline Max & 94.67 & 3167.54 & 64.02 & 12.12 & 8.14 \\
\hline $\begin{array}{l}\text { Standard } \\
\text { Deviation }\end{array}$ & 12.74 & 1214.65 & 8.41 & 1.38 & 1.16 \\
\hline $\begin{array}{l}\text { Number of } \\
\text { Observations }\end{array}$ & 148 & 129 & 143 & 168 & 161 \\
\hline
\end{tabular}

Note: P/EPS is the equity price divided by earnings per share, P/EG is the equity price divided by earnings growth per share, P/EBITDA is the equity price divided by earnings before interest, taxes, depreciation and amortization, P/SALES is the equity price divided by sales per share and $P / B V$ is the equity price divided by book value of equity per share.

Table 2 shows the prices to value drivers. The mean of price over earnings per share is 13.54 with the maximum value 94.67 of CIMB Thai Public Company Limited in 2012 and the minimum value 1.34 of Siam Commercial Bank Public Company Limited in 2001. This data indicates that the earnings are relatively high comparing to the equity prices. The median is 10.97 and the standard deviation is 12.74. The number of observations is 148 .

Second, the mean of price to earnings growth is -78.29 with the maximum value 3,167.54 of Thanachart Capital Public Company Limited in 2011 and the minimum value13,109.54 of Siam Commercial Bank Public Company Limited in 2018. The median is 20.27 and the standard deviation is $1,214.65$ which is highest from other value drivers. The number of observations is 129 .

Third, the mean of price over earnings before interest and taxes depreciation and amortization is rather high 7.80 with the maximum value 64.02 of CIMB Thai Public Company Limited in 2010 and the minimum value 0.83 of Tisco Financial Group Public Company Limited in 2001. The median is 6.57 and the standard deviation is 8.41. The number of observations is 143 .

Fourth, the mean of price over sales per share is 2.16 with the maximum value 12.12 of CIMB Thai Public Company Limited in 2001 and the minimum value 0.36 of Siam Commercial Bank Public Company Limited in 2001. The median is 2.00 and the standard deviation is 1.38 . The number of observations is 168 .

Fifth, the mean of price over book value of equity per share is rather high 1.73 with the maximum value 8.14 of CIMB Thai Public Company Limited in 2002 and the minimum value 0.43 of Kiatnakin Bank Public Company Limited in fashion sector in 2009. The median is 1.42 and the standard deviation is high 1.16 which is low compared to other value drivers. The number of observations is 161 . 
Table 3: Comparing Mean Absolute Valuation Errors of Stock Price Multiple of All Industry Sectors and Banking Sector

\begin{tabular}{|l|c|c|c|c|c|c|}
\hline & P/EPS & P/EG & P/EBITDA & P/Sales & P/BV & Composite Index of 3 drivers \\
\hline All Sectors & 0.83 & 6.40 & 0.77 & 1.45 & 0.87 & 0.72 \\
\hline Banking & 0.34 & 1.11 & 0.47 & 0.47 & 0.38 & 0.36 \\
\hline
\end{tabular}

Note: This table shows the percentage valuation errors of the mean absolute valuation error of the simple and composite multiple valuation using the stock price multiple to earnings, earnings growth, earnings before interest, taxes, depreciation and amortization, sales, book value of equity and composite index of earnings, EBITDA and book value of equity during $2001-2018$.

Table 3 compares mean absolute valuation error (MAVE) of five value drivers (i.e. EPS, earnings growth, EBITDA, sales, and book value of equity) and composite index of price multiples. The price multiple using composite index with three value drivers (EPS, EBITDA and BV) as a value driver shows the lowest valuation error 0.72 from other value drivers for all industry sectors in the SET. The finding is supported by Yoo (2006) with the evidence that the composite index of earnings, book value of equity, sales and EBITDA (earnings before interest, taxes, depreciation and amortization) multiple provides higher valuation accuracy over each simple multiple valuation. It implies that investor consider these three value drivers simultaneously when evaluating equity value.

As for the banking sector, the price multiple using earnings provides the lowest valuation error 0.34. Financial analysts of Finansia Syrus Securities and Bualuang Securities companies in Thailand also consider how future business activities affect net earnings of individual security to forecast the target price of banking firms and firms in other sectors (Bualuang Research, 2019; Vasapinyokul, 2019). This supports the finding that the net earnings are an important value driver for equity valuation for banking sector. The composite index with three value drivers (EPS, EBITDA and BV) also provides low valuation error at 0.36 . The findings imply that the integration of these three value drivers (i.e. EPS, EBITDA and BV) into a composite index also provides good valuation accuracy in the equity price analysis.

Table 4: The Accuracy of Various Value Drivers of Price Multiples

\begin{tabular}{|l|c|c|c|c|c|c|}
\hline \multicolumn{1}{|c|}{ Percentage Valuation Error } & MAVE & IQRVE & 15\% AVE & Mean & Median & Std. Dev. \\
\hline EPS & 0.34 & 0.35 & 0.63 & -0.03 & 0.04 \\
\hline EG & 1.11 & 0.52 & 0.93 & -0.35 & 0.35 \\
\hline EBITDA & 0.47 & 0.40 & 0.78 & -0.05 & 0.14 & 0.70 \\
\hline SALES & 0.47 & 0.30 & 0.79 & -0.05 & 0.18 \\
\hline BV & 0.38 & 0.36 & 0.75 & -0.03 & 0.73 \\
\hline Composite Index & 0.36 & 0.39 & 0.70 & 0.06 & 0.54 \\
\hline
\end{tabular}

Note: The percentage valuation errors are defined by the stock price less the estimated equity values divided by stock prices. This table shows the percentage valuation errors of the simple multiple valuation using the stock price multiple to earnings, earnings growth, earnings before interest, taxes, depreciation and amortization, sales, book value of equity and composite value drivers. MAVE is the mean absolute valuation errors. IQRVE is the interquartile range of valuation errors. $15 \%$ AVE is the percentage of sample whose absolute percentage valuation error is over 15 percent. Mean is the mean of non-absolute valuation error. Median is the median of non-absolute valuation error. Standard deviation is the standard deviation of non-absolute valuation error.

Table 4 shows mean absolute valuation error, interquartile range valuation error, percentage of sample whose absolute percentage valuation error is over 15 percent, mean of non-absolute valuation error, median of nonabsolute valuation error and standard deviation of nonabsolute valuation error. The mean absolute valuation errors of price multiple using EPS is the lowest at 0.34, followed by composite index with three drivers at $0.36, \mathrm{BV}$ at 0.38 , EBITDA and Sales at 0.47 and EG at 1.11. The interquartile valuation errors of all value drivers are between $0.30-0.40$ except EG with valuation error 0.52 . These figures indicate that the bulk of the valuation errors lie between $0.30-0.40$ data range and reveals the applicability of price multiple technique. All of the value drivers have samples whose absolute percentage valuation errors is over $15 \%$. The means of non-absolute valuation errors of all value drivers are close to zero except EG. The results are consistent with Liu et al.
(2002) and Yoo (2006) where the figures are close to zero meaning that the actual equity prices are close to the expected equity prices. The median valuation errors are all positive meaning that the equity is averagely overpriced and the results are consistent with the study of Yoo (2006).

\section{Conclusions, Implications, Limitations and Suggestions}

When measuring the accuracy of price multiple valuation technique in banking sector in the Stock Exchange of Thailand using mean absolute valuation error (MAVE) and percentage of sample whose absolute percentage valuation error is over 15 percent (15\% AVE) measurements, EPS is the most accuracy value driver of price multiple followed by 
the composite index (EPS, EBITDA and BV). EPS, which shows the company earnings after all the expenses are deducted, is considered as the good measurement of firm's value and important parameter in forecast equity price. Results are consistent with the practices of Thai securities companies as EPS is used to determine equity value.

Regarding composite index of price multiple, when calculating the price multiple of all sectors in the SET, the integration of three value drivers i.e. EPS, EBITDA and book value of equity into one composite index provides highest and higher valuation accuracy than simple price multiple. In banking industry, although the composite index is not the best value driver, it still provides higher measurement accuracy (low valuation error) than a single value driver of EG, EBITDA, Sales and BV. The findings show that investors consider these three financial parameters when determining equity value. As Feltham and Ohlson (1995) suggested that a firm value is related to book value of equity and earnings, the results support that investors also consider book value together with EPS and EBITDA when determining the equity value. As book value indicates business' value according to accounting numbers in the financial statements, investors and practitioners practically take the ratio of equity price to book value into consideration determining equity value. The findings are supported by Cheng and McNamara (2000) who mentioned that recent academic research studies as well as practical investment analyses report the importance of book value.

This study provides implications for investors, financial counselors, and academicians. Firstly, for investors and financial counselors, results from the present study help investors and financial counselors to select the most accurate and most applicable value driver that are appropriate for banking sector in the Thai context. Investors and financial counselors can also apply price multiple technique to evaluate equity value in other sectors applying the price multiple technique. The key criterion to get good valuation result is to select comparable firms which have similar sources of income, risk and growth. In addition, the present study analyzes and shows the equity value of companies in banking sector listed in the Stock Exchange of Thailand. Results from the present study are available to be used for future researchers to examine relevant issues. With available information on predicted equity value, future researchers, investors, and practitioners can reduce resources and time in acquiring equity price information for investment purposes.

Moreover, for academicians, although the price multiple is well-known valuation technique, the research on price multiple in Thailand is limited. The present study attempts to raise the interests of academicians and investors to apply price multiple method as a measurement of equity valuation. Findings from the present study also provide additional information for the class material and class discussions on equity price. Finally, the present research adds the new value drivers, i.e. price earnings growth and the composite index of three value drivers to determine value of the companies. Results from this research should broaden the perspectives on price multiple for academicians and practitioners. Researchers may include new value drivers and compose a new composite index as to increase the valuation accuracy.

The present study also compares and identifies the most accurate value drivers of different value drivers of price multiple in banking sector in Stock Exchange of Thailand. Researchers can apply the price multiple technique finding the most accurate value driver for other sectors and markets. Investors and practitioners, then, can select the most accuracy and appropriate value drivers to forecast the firms' value.

The present study is subjected to some limitations. First, the present study is subjected to missing data (prices or value drivers figures of some firms in some years are not available) for analyzing the value of equity. The missing data could cause high valuation error. Future research may incorporate more or additional data to increase the accuracy of results. Second, although the present research introduces and develops new composite index of price multiple, valuation accuracy may increase with other types of composite index. For example, non-linear combination of the simple multiple valuation outcomes of forward earnings multiple and historical multiples. In addition, composite index composed by the regression results to estimate the weights on each simple value driver is also recommended for future research. Third, the present study does not compare valuation accuracy of price multiple technique with other techniques, such as discount cash flow or economic value added. Future research may compare the valuation accuracy of different valuation forecast technique to find the best measurement of value of firms listed in the stock exchange market of Thailand or other stock markets.

Finally, future research may apply price multiple technique to measure value of the firms and forecast future prices in other emerging equity markets and developed equity markets since there may be differences in the nature of each equity market that can influence the accuracy of various value drivers of price multiple.

\section{References}

Asquith, P., Pathak, P. A., \& Ritter, J. R. (2005). Short interest, institutional ownership, and stock returns. Journal of Financial Economics, 78, 243-276.

Baker, M., \& Ruback, R. (1999). Estimating industry multiples. Cambridge, MA: Harvard Business School.

Beatty, R., Riffe, S., \& Thompson, R. (1999). The method of comparable and tax court valuation of private firms: An empirical investigation. Accounting Horizon, 13(3), 177199.

Bekaert, G., \& Harvey, C. R. (2013). Emerging equity markets in a globalizing world. Working paper, New York, NY: Columbia Business School.

Bhojraj, S., \& Lee, C. (2002). Who is my peer? A valuationbased approach to the selection of comparable firms. Journal of Accounting Research, 40(2), 407-439. 
Bradshaw, M. (2004). How do analysts use their earnings forecasts in generating stock recommendations? The Accounting Review, 79(1), 25-50.

Bualuang Research (2019). Bangkok, Thailand. Retrieved June 23, 2019, from https://blsport2.bualuang.co.th/\#pretrade/research.

Cheng, C. A., \& McNamara, R. (2000). The Valuation accuracy of the price-earnings and price-book benchmark valuation methods. Review of Quantitative Finance and Accounting, 15(4), 349-370.

Demirakos, E. G., Strong, N., \& Walker, M. (2004). The valuation methodologies of financial analysts. Working paper, University of Manchester.

Damodaran, A. (2001). Its all relative: First principles of relative valuation. Working Paper, New York, NY: New York University.

Damodaran, A. (2009). Volatility rules: Valuing emerging market companies. New York, NY: Stern Business School.

Feltham, G., \& Ohlson, J. A. (1995). Valuation and clean surplus accounting for operating and financial activities. Contemporary Accounting Research, 11(2), 689-731.

Kaplan, S., \& Ruback, R. (1995). The valuation of cash flow forecasts: An empirical analysis. The Journal of Finance, 50(4), 1059-1093.
Kim, M., \& Ritter, J. (1999). Valuing IPOs. Journal of Financial Economics, 53(3), 409-437.

Liu, J., Nissim, D., \& Thomas, J. (2002). Equity valuation using multiples. Journal of Accounting Research, 40(1), 135-172.

Market Statistics (2019). Bangkok, Thailand. Retrieved June 23, 2019, from https://www.set.or.th/th/market/market_statistics.html.

Nel, W. S. (2009). Methods of choice in the valuation of ordinary shareholders' equity: Evidence from theory and practice. Meditari Accountancy Research, 17(2), 117-135.

Sayed, S. A. (2016). Does sophisticated DCF outperform heuristics driven PE? Evidence from India. Journal of Advances in Management Research, 13(1), 42-58.

Tasker, S. (1998). Industry preferred multiples in acquisition valuation. Working Paper, Ithaca, NY: Cornell University.

Vasapinyokul, S. (2019). Fundamental Analysis. Finansia SBI Thai Online. Bangkok, Thailand. Retrieved June 23, 2019, from https://www.fnsyrus.com/uploads/research/190424Banks _1Q19Results.pdf.

Yoo, Y. K. (2006). The valuation accuracy of equity valuation using a combination of multiples. Review of Accounting and Finance, 5(2), 108-123. 